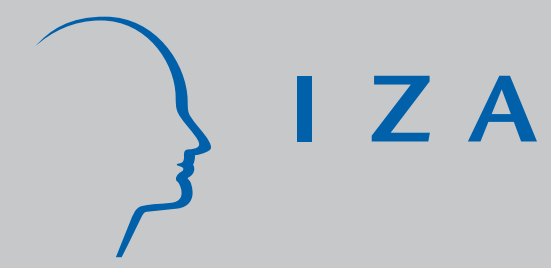

IZA DP No. 347

Labor Market Conditions and Post-Reform Declines in Welfare Receipt Among Immigrants

Magnus Lofstrom

Frank D. Bean

August 2001 


\title{
Labor Market Conditions and Post- Reform Declines in Welfare Receipt Among Immigrants
}

\author{
Magnus Lofstrom \\ University of California at Irvine and IZA, Bonn
}

Frank D. Bean

University of California at Irvine

Discussion Paper No. 347

August 2001

\author{
IZA \\ P.O. Box 7240 \\ D-53072 Bonn \\ Germany \\ Tel.: +49-228-3894-0 \\ Fax: +49-228-3894-210 \\ Email: iza@iza.org
}

This Discussion Paper is issued within the framework of IZA's research area The Welfare State and Labor Markets. Any opinions expressed here are those of the author(s) and not those of the institute. Research disseminated by IZA may include views on policy, but the institute itself takes no institutional policy positions.

The Institute for the Study of Labor (IZA) in Bonn is a local and virtual international research center and a place of communication between science, politics and business. IZA is an independent, nonprofit limited liability company (Gesellschaft mit beschränkter Haftung) supported by the Deutsche Post AG. The center is associated with the University of Bonn and offers a stimulating research environment through its research networks, research support, and visitors and doctoral programs. IZA engages in (i) original and internationally competitive research in all fields of labor economics, (ii) development of policy concepts, and (iii) dissemination of research results and concepts to the interested public. The current research program deals with (1) mobility and flexibility of labor markets, (2) internationalization of labor markets and European integration, (3) the welfare state and labor markets, (4) labor markets in transition, (5) the future of work, (6) project evaluation and (7) general labor economics.

IZA Discussion Papers often represent preliminary work and are circulated to encourage discussion. Citation of such a paper should account for its provisional character. 


\section{ABSTRACT \\ Labor Market Conditions and Post-Reform Declines in Welfare Receipt Among Immigrants*}

Considerable research attention has been devoted to the question of whether and to what extent changes in welfare policy legislated in the 1990s might have deterred immigrant participation in welfare programs, although only post-1996 immigrants were explicitly targeted by most of the changes. Some analysts have argued that such so-called chilling effects have lowered immigrant participation, and others have argued that this is true only in California. This paper analyzes the role of local labor market conditions in explaining declines in the welfare participation trends of immigrants and reductions in the nativity participation gap for the period 1994 to 1999. The data, extracted from the March Current Population Survey, indicate that immigrants' participation in welfare declined more rapidly than natives' during the latter half of the decade. Our results show that variation in the unemployment and employment rates across MSAs and states explain the observed relative post-welfare reform decrease among immigrants, with immigrant welfare utilization being sensitive to changes in both employment and unemployment rates. The inclusion of state fixed effects in probability models suggests that the relative decline among immigrants is not due to unobservable heterogeneity across states, but rather to differences in local labor market conditions. The policy implications of the findings are discussed.

JEL Classification: H53, I30, I38, J15, J61

Keywords: Immigrant welfare, welfare reform, labor market conditions

Magnus Lofstrom

University of California at Irvine

School of Social Sciences

3151 Social Science Plaza

Irvine, CA 92697-5100

USA

Email: mlofstro@uci.edu

\footnotetext{
* The support of grants from NICHD (HD-39075) and the Hewlett Foundation is gratefully acknowledged. We thank John DiNardo, Jeff Grogger, Steve Haider, Ron Lee, Bob Schoeni and particpants of seminars at UC Berkeley and UCLA for helpful comments.

(C) 2001 by Magnus Lofstrom and Frank D. Bean. All rights reserved. Short sections of text, not to exceed two paragraphs, may be quoted without explicit permission provided that full credit, including (C notice, is given to the source.
} 


\section{Labor Market Conditions and Post-Reform Declines in Welfare Receipt Among Immigrants}

\section{Introduction}

The issue of immigrant welfare recipiency played a major role in national debates during the early 1990s regarding the need to reform both immigration and welfare policy (Bean, et al, 1997; Van Hook, Glick, and Bean, 1999). Concern that such recipiency might be increasing contributed to the passage in 1996 of the Personal Responsibility and Work Opportunity Reconciliation Act (PRWORA) (Borjas, 1999), legislation designed in part to restrict the access to welfare benefits of non-citizens coming to the United States after August 22, 1996 (Fix and Passel, 1999; Capps, 2001). In the latter half of the 1990s, the United States has experienced both the strongest economic growth of the twentieth century and a substantial decrease in welfare caseloads nationally (Penner, Sawhill and Taylor, 2000; Danziger, 1999). A number of studies have investigated the extent to which these economic changes, as opposed to welfare policy shifts, have contributed to the declines in caseload. For the most part, the studies have found that economic improvements during the 1990s mattered more than policy changes in bringing about caseload reductions (Bell, 2000; Moffit, 1999; Schoeni and Blank, 2000). A few studies have also documented that welfare declines among immigrants exceeded those of natives during this period (Fix and Passel, 1999; Borjas, 2001). However, the extent to which immigrant and native welfare declines are equally likely (or not) to be explained by changes in economic conditions remains unknown.

This research addresses this question by examining the extent to which nativity differences in the level and movement of welfare recipiency relate to nativity differences and 
changes in labor market conditions from 1994 to 1999 . We do so by first calculating what to our knowledge are the first intercensal areal estimates of annual immigrant welfare receipt and immigrant labor market conditions, using information on nativity available in the Current Population Survey (CPS) only since January 1, 1994. As we note below, some of the estimates are volatile because the sample sizes for immigrants in some of the areas are small. The estimates are nonetheless useful because intercensal information on immigrant labor market conditions has heretofore been lacking. Moreover, any volatility in the estimates would engender a conservative bias against the likelihood of detection of statistically significant labor market effects.

When we examine the estimates over the period 1994-1999, we see that the receipt of (any form of) welfare among native households declined from 15.5 to 13.2 percent. Among immigrant households, participation in any program fell from 23.6 to 19.7 percent, a reduction in the nativity recipiency gap from 8.1 to 6.5 percentage points, (see Table A1). The decline in the gap in some of the individual programs was even more striking. For example, the difference between immigrant and native households in AFDC participation was 2.6 percentage points in 1994. This gap dropped by more than half by 1999 (then TANF), to 1.1 percentage points. What accounts for such a differential decline? Are factors such as nativity differences and changes in demographic composition responsible for the larger welfare decline among immigrants? Have immigrants been differently affected by welfare reform than natives? Or have they been differentially influenced by changes in economic conditions? These are the questions the present research seeks to answer. 


\section{Background, Rationale, and Hypotheses}

The 1996 reforms in federal welfare law placed explicit restrictions on noncitizen eligibility for receipt of Temporary Assistance for Needy Families (TANF), food stamps, Medicaid, Supplemental Security Income (SSI) and other health and social service programs. This is particularly the case for immigrants coming to the United States after August 22, 1996. The law also gave states the option of extending some of these benefits to noncitizen immigrants, and many have done so, although the number of programs restored has varied substantially across states (Zimmerman and Tumlin, 1999). Thus, the law has led to substantial state differences in the availability of programs providing benefits to non-citizen immigrants. It may also have generated considerable confusion among immigrants concerning whether or not they are eligible for public services. The change in the law itself may thus have caused greater declines in welfare receipt among immigrants because of perceptions that the law's restrictions constituted a strong signal of host country inhospitality, discouraging immigrants from applying for benefits for which they were eligible, either for reasons of confusion or intimidation.

Some observers have advanced the argument that such "chilling effects" have taken place, citing reports of sharper declines in receipt among non-citizens as supporting evidence (Fix and Passel, 1999; Zimmerman and Fix, 1998). Others have countered that evidence of such effects has not emerged except perhaps in the case in California, a result that is attributed to the general atmosphere there immediately before and after 1994 when Proposition 187 banning immigrant use of public services was passed (Borjas, 2001). Whatever the case, it is preferable to search for more general explanations of patterns of differential decline than to rely on post hoc hypotheses emphasizing the idiosyncratic properties of single states. Changes in labor market conditions over this time period offer a potential explanation, one that not only accounts for the 
differential welfare decline by nativity in general, but also for the especially sharp nativity difference in trends that have emerged in California.

Previous research has found evidence of greater sensitivity, in welfare participation, to changes in local labor market conditions among minorities, including blacks and Hispanics (Hoynes, 2000). The same is also likely the case for low-skilled immigrants. Substantial evidence, including workplace fatality data, indicates that immigrants are disproportionately concentrated in low-skilled jobs in the economy (Greenhouse, 2001). Despite the fact that in the United States the educational distribution of recent immigrants is roughly bimodal, with the percentage of immigrants with a college education being approximately the same as that for natives, the percentage with less than a high school education is substantially higher (Betts and Lofstrom, 2000: Bean, Gonzalez-Baker, and Capps, 2001). Moreover, because of both their immigration status and their minority status, many immigrants are consigned to the lower reaches of the job distribution to a greater degree than would be expected based on their education level (DeJong and Madamba, 2001; Raijman and Tienda, 1999). And this makes a difference for labor market outcomes, resulting for immigrants in higher unemployment, underemployment, and employment instability than among similar natives (Hsueh and Tienda, 1995).

Immigrants are thus likely to experience more precarious labor market attachments than natives, implying that they are among the least likely (and the last) to be hired during times of economic prosperity and among the most likely (and the first) to be laid off during times of economic difficulty. Thus, immigrants are probably subject to sharper swings in labor market outcomes than natives with fluctuations in the business cycle and likely to manifest sharper swings in the degree of welfare recipiency. As a result, we would expect measures of immigrant 
unemployment and employment rates to vary more over time than they do for natives. Figures 1 and 2 suggest that this is the case, showing that immigrant labor market conditions improved relative to natives during the post-reform period. We would also expect nativity differences in levels and changes in labor market conditions to account for a substantial part of nativity differences in levels and movements in welfare recipiency during the latter half of the 1990s, net of other factors that might be expected to influence welfare recipiency across places and time.

\section{Data and Welfare Participation Trends}

To analyze differences in welfare trends between immigrants and natives, we use data drawn from the 1995-2000 March Current Population Surveys (CPS). ${ }^{1}$ We focus our attention on the latter half of the 1990s because the Current Population Survey (CPS), which provides the information we use to measure nativity specific labor market conditions, only began asking questions that provided information about nativity in January, 1994. The unit of analysis is the household and we let the head of the household's socio-economic characteristics, such as age and education, represent the household. Consequently, a household will be defined as an immigrant household if the household head is foreign born and native if the household head was born in the U.S. ${ }^{2}$ Using the household as the unit of analysis can entail limitations. For example, as compared to using families or individuals, it maximizes nativity differences in welfare receipt (Van Hook, Glick and Bean, 1999). This is appropriate in the present case because we want to test the influence of labor market conditions on nativity gaps in receipt. Another justification for

\footnotetext{
${ }^{1}$ There are some concerns about the accuracy of the 1994 March CPS, the earliest year of survey participant's immigrant status, regarding the accurate enumeration of the immigrant population, see e.g. Passel (1996). For that reason, we do not incorporate individual data from the 1994 CPS in our analysis. However, we use the 1994 data to calculate local unemployment and employment measures.

${ }^{2}$ We do not separate between naturalized and non-naturalized immigrants in our empirical analysis since the decision of applying for U.S. citizenship itself may be affected by the 1996 welfare reform and hence be endogenous.
} 
using the household as the unit of analysis is that eligibility and receipt of welfare are generally based on household composition and household income.

The public assistance programs included in our analyses are the major components of welfare assistance: Supplemental Security Income (SSI), food stamps, Medicaid and Aid to Families with Dependent Children (AFDC) which was replaced by Temporary Aid for Needy Families (TANF) in 1996. Table 1 shows mean probabilities of household participation in any of these programs before and after the 1996 welfare reform act. $^{3}$ As noted above, immigrant welfare participation declined more rapidly among immigrants than natives after the welfare reform, a drop by 3.7 percentage points, compared to a 1.7 percentage decline observed among native households. ${ }^{4}$ Also mentioned earlier, the table shows the dramatic relative decline among immigrants in California, where immigrant participation in public assistance dropped by 7.4 percentage points in the post-reform period while native participation dropped by a relatively modest 1.5 percentage points. If we exclude California from the sample, the immigrant participation decline is very similar to the native decline, as was shown by Borjas (2001). However, Table 1 also indicates that in another large state, namely New York, immigrant welfare receipt increased both absolutely and relative to natives. If we exclude both California and New York, the relative changes for all other states are quite similar to the overall change in the United States. But explanations for the relative decline in participation among immigrants need to go further than simply to exclude states where many immigrants reside and where the patterns vary. Here we focus on changes in labor market conditions.

The measures that we use to reflect local labor market conditions are the unemployment rate and the employment-to-population ratio for the working age population (age 18-65). These

\footnotetext{
${ }^{3}$ We the define pre-reform years as $1994-95$ and the post-reform years as 1997-99.
} 
are calculated separately for immigrants and natives by Metropolitan Statistical Areas (MSA) or states, depending on the number of observations in the area, for each of the years, 1994-1999. Due to the sample size of the CPS data, there is a limit to the number of MSAs for which we can calculate these labor market measures reasonably accurately. To deal with this limitation, we focus on the number of immigrants, the smaller of the two groups, in the working age population, age 18-65, included in the CPS for each year by state and MSA. If we can identify at least 50 working age immigrant respondents in each year in the geographic area, we calculate the unemployment rate and the employment-to-population ratio for immigrants and natives separately.

This approach yields 10 states and 14 MSAs (in parentheses) within these 10 states; Arizona, California (Los Angeles/Long Beach, Orange County, San Diego, San Jose, Riverside/San Bernardino and San Francisco), Florida (Fort Lauderdale and Miami), Illinois, Massachusetts, Michigan, Nevada, New Jersey (Bergen-Passaic, Jersey City and Newark), New York (New York) and Texas (Dallas and Houston). Note that not all of the 10 states have a sufficiently large immigrant population to allow us to identify labor market conditions by MSA. Also note that in all the states where the sample is sufficiently large to calculate the labor market measures for at least one MSA, we also calculate the labor market measures for the rest of the state. For example, in Texas we calculate, separately for immigrants and natives, the annual unemployment rate and employment-to-population ratio for 3 areas; Dallas, Houston and the remainder of Texas. In total, we identify 25 local labor markets. The overall period unemployment and employment rates, as well as standard deviation and sample size, for these areas are shown in appendix Table A1. 
As noted above, the immigrant-native welfare participation gap dropped in the post welfare reform period. Table 1 also shows that labor market conditions improved more strongly among immigrants than natives. The unemployment gap between immigrants and natives dropped between the pre and post reform period from 2.7 percentage points to 1 percentage point. The relative employment situation also improved for immigrants. Employment increased more rapidly among immigrants than natives after the welfare reform, an increase by 3 percentage points for immigrants, as compared to the 0.6 percentage point increase observed among natives.

Not surprisingly, welfare and labor market trends differ across the geographic areas defined above. Table 2 shows welfare participation as well as the labor market conditions before and after the 1996 welfare reform for the largest immigrants MSAs, such as Los Angeles, New York and Miami, and a few other representative large areas. Of these areas, among natives, welfare participation dropped most dramatically in Houston, by 9.6 percentage points. Immigrant welfare utilization also dropped for immigrants in Houston in the post reform period, but not by as much, by 8.1 percent. A look at the relative changes in labor market conditions reveal that the unemployment rate declined by 2 and 0.2 percentage points for natives and immigrants respectively in Houston. The employment rate increased by a percentage point in this MSA for natives while it declined by 5.7 percentage points for immigrants. It appears that immigrants did not enjoy as favorable post welfare reform labor market conditions in Houston as natives, and this may be one reason immigrant welfare participation did not drop as much as among natives.

For immigrants, the largest welfare decline was in Orange County, California. Here, participation went down by 15.6 percentage points for immigrants and by 1.1 percentage points among natives. In other words, the relative welfare trend in Orange County is reversed compared 
to the one observed in Houston. In this geographic area, immigrants enjoyed impressive relative labor market improvement, compared to natives, in the post 1996 period. The immigrant unemployment rate dropped by 5.9 percentage points ( 3.3 percentage points for natives) and the employment rate increased by 14.6 percentage (1.1 percentage points natives).

This pattern of differences in immigrant and native welfare usage and labor market conditions is not totally clear in all areas. Table 2 also shows that immigrants in New York City increased their participation in public assistance, both absolutely and relatively to natives. This occurred even though labor market conditions improved more for immigrants than they did for natives. Other factors, such as demographic changes in the area, might partly explain the relationship between labor market conditions and the welfare trend and hence will be incorporated into our econometric analysis below. Nonetheless, on the surface, at least, Table 2 suggests that differential labor market trends among immigrant and natives may be partially responsible for the relative decline in welfare participation among immigrants.

\section{Statistical Models}

As pointed out above, the concurrent observed relative decline in immigrant welfare participation and improved labor market conditions suggests that changes in the labor market situations facing immigrants may at least partially explain the different welfare trends among immigrants and natives. To analyze the relationship between local labor market conditions and welfare participation more systematically, we estimate welfare probability models. The methodology adopted utilizes pooled CPS data for the years 1994-99, but excludes the year of welfare reform, $1996 .{ }^{5}$ We further restrict the sample to only include the working age population,

\footnotetext{
${ }^{5}$ Since welfare participation in the CPS refers to the year prior to the survey, this means that we are using March CPS data for each of the years 1995-2000, excluding data from the 1997 March CPS.
} 
age 18-65. The dependent variable is a dichotomous variable equal to one if the household received SSI, food stamps, Medicaid or AFDC/TANF, and zero if the household did not participate in any of these welfare programs. To analyze the impact of the local labor market conditions on post-welfare reform participation, we use a difference-in-difference model according to the following general specification:

$$
\begin{aligned}
\mathbf{W F P}_{i t} & =\mathbf{X}_{i t} \beta+\alpha \text { POST1996 }_{i t}+\delta \text { Immigrant }_{i t}+\gamma\left(\text { POST1996 }_{i t} * \text { Immigrant }_{i t}\right) \\
& +\lambda \text { Unemp }_{i t}+\tau \text { Empl }_{i t}+\varepsilon_{i t}
\end{aligned}
$$

where $\mathbf{X}$ is a matrix of socioeconomic characteristics of the householder (age, education, gender, marital status, and for immigrants, indicator variables for arrival cohort) and household characteristics (number of individuals in the household, number of children under the age of 18 and a dummy variable for urban household), POST1996 is a dummy variable for the post welfare reform years, i.e. 1997, 1998 and 1999, Immigrant is a dichotomous variable indicating whether the household head is an immigrant or native born individual. The unemployment rate, Unemp, and the employment-to-population ratio, Empl, are used as measures for the local labor market conditions, defined above.

This specification allows us to interpret the POST1996 coefficient, $\alpha$, as the post welfare reform change in welfare participation among natives while the immigrant post welfare reform decline is captured by $\alpha$ plus $\gamma$, the coefficient of the interaction term, POST1996*Immigrant. Of particular importance is the coefficient $\gamma$, which captures the difference-in-difference effect of the trend before and after welfare reform between native and immigrant households. The results presented below are based on linear probability models. These models were also estimated by probit because of well known concerns regarding the properties of OLS models using dichotomous dependent variables. The probit results were very similar to the linear results and 
our conclusions are not sensitive to the functional form used. Due to the ease of interpretation of the estimated coefficients from applying OLS to the above model, we only present results in the case of the linear probability model.

\section{Results}

Model 1 in Table 3 shows that native welfare utilization for the working age population declined by 2 percentage points in the post-welfare reform period (i.e. the 1997-99 period) compared to the pre-welfare reform years (1994-99). Immigrant participation declined by an additional 2.2 percentage points. However, these estimates do not take into account any possible changes in demographic composition. When controls for age, education, urban residence, gender, marital status, number of individuals in the household, number of children under the age of 18, and for immigrants, arrival cohort (the reference cohort is the post-1992 arrival cohort) are added to Model 1, the extent to which immigrant welfare receipt declines more rapidly than native receipt drops slightly to 1.8 percentage points, indicating that more than 80 percent of the differential cannot be attributed to differences and changes in composition (see Model 2 in Table $3)$.

The welfare participation trend may also be partially explained by factors that are specific to the states, but unobservable to the analyst. To investigate this possibility, we add "immigrant state" fixed effects to Model 2. Shown as Model 3, the relative immigrant participation decrease does not appear to be affected by the inclusion of the state fixed effects. ${ }^{6}$ Neither of the postwelfare reform coefficients, $\alpha$ or $\gamma$, change from Model 2 to Model 3. This may not be very

\footnotetext{
${ }^{6}$ The so called "immigrant states" are the 10 states with the largest immigrant population; Arizona, California, Florida, Illinois, Massachusetts, Michigan, Nevada, New Jersey, New York and Texas. Close to 80 percent of the immigrant population reside in one of these states. The results are not sensitive to whether we include "immigrant state" fixed effects, state fixed effects or fixed effects for the geographic areas defined in Table A2.
} 
surprising since the inclusion of state fixed effects imposes a mean state effect that is equal for natives and immigrants. The descriptive data discussed above indicated that labor markets may have changed differentially for immigrants and natives and that these effects varied across states and MSAs. To analyze the effects of local labor market conditions, we next add controls for unemployment and employment.

Model 4 includes variables for the local unemployment rate and employment-topopulation ratio. Both variables yield the expected sign and are statistically significant. What may be of more interest is that the difference-in-difference coefficient indicates that immigrant welfare participation declined no more than native welfare participation in the post-welfare reform period, once labor market conditions are taken into account. The estimated coefficient, $\gamma$, drops by approximately two-thirds compared to its values in Model 2, and Model 3, and becomes statistically insignificant. Thus, roughly two-thirds, and possibly all, of the relatively greater decline among immigrant household can be explained by differences in the local labor market conditions experienced by the two groups. This is the key finding of this paper; we next check the robustness of this result.

\section{Robustness of Findings}

It is possible that the above results are due to a "spurious" relationship between our measures of labor market conditions and some unobserved state specific factor. To address this possibility we also estimate Model 4 including "immigrant state" fixed effects, and present the results as Model 5. The findings indicate that our specification in Model 4 is not sensitive to this possibility. The results in Model 4 and 5 are quite similar with only minor differences, namely, the magnitude of the estimated impact of unemployment and employment drops slightly and the 
standard error of these coefficients increases somewhat. The estimated difference-in-difference effect increases slightly (from -0.006 to -0.007 ) but remains insignificant.

The specification in Models 4 and 5 imposes the restriction that changes in unemployment and employment have an equal effect on welfare participation propensities for immigrant and native households. To test whether changes in local labor market conditions affect immigrant welfare participation to the same extent as among natives, we add interactions between the immigrant indicator variable and the unemployment and the employment rates. The results, shown as Model 6, indicate that immigrant and native welfare participation are not affected differently by changes in the unemployment and employment conditions. Both estimated coefficients for the interacted labor market condition variables are negative, suggesting that immigrants may be less sensitive to changes in unemployment rates and more sensitive to changes in employment rates than natives. However, both coefficients are statistically insignificant at conventional levels. Of course, this may be due to more "noise" in the labor market variables for immigrants as a result of their smaller sample size, i.e. fewer immigrants in each area defined. Finally, when we add "immigrant state" fixed effects to Model 6, presented as Model 7, we find that these results are not affected appreciably.

Although Congress passed legislation in 1996 that restricted access to welfare to noncitizen immigrants, several states extended their public assistance safety net to immigrants who are not eligible under the federal regulations. This has potential implications for our analysis. If there is a relationship between labor market conditions and state granted immigrant access to welfare, the unemployment and employment effects could be due to this. However, to think this, one would need also to argue that states with strong economic growth during the period were states that did not restore access to immigrants who were not eligible under PRWORA, given the 
estimated relationships between welfare participation and labor market conditions. This seems somewhat unlikely given that California experienced strong economic growth and was one of the most generous states in having restored benefits to immigrants. Nonetheless, to test this possibility, we incorporate into our models a measure of state specific immigrant welfare availability based on the Urban Institute's state specific index which reflects the degree of social restoration assistance granted to immigrants by states. We also incorporate a measure of the overall welfare generosity by including the TANF benefit level for a family of three in 1997. The results are presented as Model 8 in Table 3. The inclusion of welfare benefit levels and immigrant welfare access do not change the estimated impacts of local area unemployment and employment. Furthermore, the difference-in-difference estimate, $\gamma$, remains insignificant. Note that it is not possible to include state fixed effects in the models that include these time invariant measures. For this reason, the appropriate comparison model for Model 8 is with Model 4.

The above estimated models analyze participation probabilities in any of the four welfare programs, AFDC/TANF, SSI, food stamps or Medicaid. As Table A1 shows, immigrants participation has declined more rapidly in each program than natives, but most strongly for AFDC/TANF and food stamps. Questions remain concerning whether any particular program might be driving our results, and whether local labor market conditions might affect the welfare trends differently in these programs. To shed light on these possibilities we estimate separate probability models for participation in each of the above public assistance programs. The results are shown in Table 4. In order to save space, we present only the results for the most relevant models, Models 2 and 4 in Table 3.

The results show that the greater relative decline in participation among immigrants in each of the welfare programs included in this paper are all to a great extent explained by local 
labor market conditions. In fact, the immigrant post welfare reform trend appears to be due to differences in employment and unemployment in all programs except food stamps. However, even in this program, labor market conditions explain roughly 40 percent of the stronger participation decline among immigrants. Overall, it appears that differential welfare utilization trends between immigrants and natives in all four programs are sensitive to local labor market conditions, and that the above reported results for omnibus participation are not driven by any one program in particular.

At this point, it is useful to ask here whether still other factors might account for the findings, especially factors related to the improvements in economic conditions that might plausibly account for more rapid decline in immigrant welfare receipt? One possible factor in this regard is growing labor supply. The increasingly strong job market in the United States over this period may have increasingly pulled into the United States labor migrants who were busy working because of the availability of jobs and who thus did not contribute to higher welfare recipiency rates. Unauthorized migrants from Mexico who had children born after they came to the United States would have constituted a group who also would have been eligible for welfare but who might not have applied for it. If increasing numbers of such person came and showed up in the CPS but not on the welfare rolls, perhaps this could account for the declining rates of recipiency among immigrants? If this were true, however, the greater declines among immigrants should disappear when we remove the most recent arrivals from the analyses. To address this concern we re-estimated the models in Table 3. The results did not alter the conclusions reached above (results available from the authors upon request). Also note that the Models 2-8 in Table 3 include dummy variables for arrival cohort. If there were simply a mean 
difference between the most recent cohort and previous cohorts, adding the cohort dummies would control for such above discussed potential supply effects.

Another factor is the arrival after August 22, 1996 of legal immigrants not eligible for welfare receipt because of the cut-off date in the welfare reform legislation. These persons could also have accumulated in the denominator (i.e., because they could be in the CPS), but they would not have been eligible to apply for welfare because they would not have been in the country long enough according to the provisions of the new law. But here again, if this were the case, removing from the analyses persons who reported they had come to the United States within the past couple of years should lead to a substantial elimination of the effect we observed. However, this is not what we found, leading us again to conclude that this is not a factor that could plausibly account for the findings.

Another possibility may appear to derive from our small sample sizes in the cases of some of the estimates of labor market conditions. In those areas where we have small numbers of observations, the data would seem to contain less independence concerning the calculation of the labor market condition measure and whether a person reported welfare receipt. That is, a person reporting welfare receipt might also appear to constitute one of the observations on which the labor market conditions for that area were calculated. However, it should be remembered that these measures come from different years of the CPS. Thus, the receipt of welfare is measured from a CPS at time t, and the labor market conditions for that person at time $\mathrm{t}-1$. Hence, dependence between measurements is not likely to account for the results. 


\section{Summary and Discussion}

Using Current Population Survey data, this research investigates the degree to which changing labor market conditions have contributed to the relatively greater declines in welfare receipt occurring among immigrants compared to natives from 1994-1999. In order to address this question, the research constructs metropolitan and state-level indicators of nativity-specific unemployment and employment rates, measures that had not previously been available because of lack of data in government surveys on country of birth. This information has been collected in the CPS since January 1, 1994. Based on the notion that many immigrants constitute a disadvantaged source of labor, and thus one especially subject to the vagaries of the business cycle, we argue that immigrant levels of unemployment and employment would be more adversely affected during times of economic retrenchment than those of natives, and subsequently recover more during times of strong economic growth. Such ideas provide a framework for not only predicting sharper welfare declines among immigrants, but also steeper declines in states that suffer the sharpest swings in the business cycle, thus avoiding the need to invoke idiosyncratic explanations of nativity and state patterns.

The main finding of the research is that levels and changes in labor market conditions explain between two-thirds to all of the relatively greater decline among immigrants in welfare receipt over the period examined. This result is robust to checks on the possibility that other properties of the areas in which immigrants and natives reside might account for the patterns. These include tests that show negligible state-level fixed effects and state-level welfare generosity accounting for only a small portion of differential nativity change. Also, when estimates were obtained by adding employment and unemployment rates sequentially to the models (not shown here but available upon request), the effects on welfare participation were 
slightly stronger for the labor market measure of unemployment than employment. This is a finding that mirrors the fact that most low-skilled immigrants are labor migrants (the national origin composition of this group being dominated by persons of Mexican origin, who are almost exclusively labor migrants). The labor market and welfare behavior of such migrants may reflect the influence of such low reservation wages that migrant labor supply essentially becomes a function of job availability.

Finally, what are the policy implications of the findings? In addressing this question, it is important to note first that previous research has documented steeper declines in welfare receipt among immigrants over at least a portion of this period (Fix and Passel, 1999; Borjas, 2001). Because this decline has seemed to be sharpest among non-citizens, Fix and Passel (1999) argue that it reflects a "chilling" effect associated with welfare reform indicating either immigrant confusion about how changes in the law applied to them or perhaps even intimidation on the part of immigrants concerning the possibility of deportation under the law's strengthened "public charge" provisions. Although Fix and Passel (1999) do not set forth explicit policy recommendations, possibilities that would seem to follow from their findings might involve either more education concerning the law's actual provisions, more careful implementation in order to make sure the actual provisions instead of harsher practices are applied, or perhaps even repeal of the law itself.

However, there are reasons to question whether the recent immigrant declines in welfare receipt are due to such "chilling" effects per se. For one thing, the possibility cannot be ruled out that many of the non-citizens most likely to receive welfare simply may have naturalized in the years immediately after welfare reform. While this may indeed result from confusion on the part of non-citizens, since in fact immigrants who were already in the country before August, 1996 
did not have to naturalize to continue to receive benefits, it also provides an explanation other than chilling effects for the declines in receipt among non-citizens. Such declines could have occurred because of the disproportionate movement of high receipt households into the naturalized category, thus raising the average receipt level among naturalized immigrants (assuming receipts were higher among non-citizens to begin with, which in fact is the case). This possible change in naturalization behavior has also been noted by Borjas (2001), who interprets it as indication that immigrants are attracted to naturalization by welfare ("Many immigrants will become citizens not because they want to fully participate in the U.S. political system, but because naturalization is a hurdle on the road to receiving welfare benefits."). In fact, he argues in general that welfare is one of the factors that attracts immigrants to the United States. As a result, his recommended policy solution is to make it more difficult to immigrate: "In the end, it is probably easier and cheaper to address the problem raised by the immigration of public charges not by 'ending welfare as we know it,' but by reforming immigration policy itself" (Borjas, 2001: 18).

The perspective on policy implications that we offer here does not emphasize reform of either the social welfare system or immigration policy. Rather it derives from this research's finding that changes in labor market conditions account for almost all of the declines in both immigrant welfare receipt and the nativity gap during the latter half of the 1990s. Given that improvements in labor market conditions have led to substantial declines in participation, especially among immigrants, it is likely that any new emergence of deteriorating economic conditions would have substantial negative implications for future immigrant welfare receipt. In short, increases in immigrant welfare in the future are likely to owe to increased unemployment and decreased employment possibilities. From a policy standpoint these need to be addressed on 
their own terms. The possibility of their amelioration requires the consideration and possible adoption of policies and programs that minimize the harsher effects that adverse labor market conditions impose on immigrants compared to natives. 


\section{References}

Bean, Frank D, Robert G. Cushing, Charles W. Haynes, and Jennifer V. W. Van Hook. 1997. "Immigration and the Social Contract," Social Science Quarterly, 78:432-51.

Bean, Frank D, Susan Gonzalez-Baker and Randy Capps. 2001. "Immigration and Labor Markets in the United States," Pp. 669-703 in Sourcebook of Labor Markets: Evolving Structures and Processes, Ivar Berg and Arne L. Kalleberg, eds. Kluwer Academic/Plenum Publishers, New York.

Betts, Julian R. and Magnus Lofstrom. 2000. "The Educational Attainment of Immigrants: Trends and Implications," in George J. Borjas, ed. Issues in the Economics of Immigration. University of Chicago Press, pp. 51-115.

Bell, Stephen H. 2001. "Why Are Welfare Caseloads Falling?” The Urban Institute, No. 01-02.

Blank, Rebecca M. 1989. "Analyzing the Length of Welfare Spells," Journal of Public Economics, 39(3), 245-273.

Blank, Rebecca M. and Patricia Ruggles. 1996. "When Do Women Use Aid to Families with Dependent Children and Food Stamps? The Dynamics of Eligibility versus Participation," Journal of Human Resources, 31(1), 57-89.

Borjas, George J. and Hilton, Lynette. 1996. "Immigration and the Welfare State: Immigrant Participation in means-tested Entitlement Programs", Quarterly Journal of Economics 111(2), 575-604.

Borjas, George J. 1999. Heaven's Door: Immigration Policy and the American Economy, Princeton University Press.

Borjas, George J. 2001. "Welfare Reform and Immigration," in The New World of Welfare, Rebecca M. Blank and Ron Haskins, eds. Washington, D.C. Brookings Press.

Capps, Randy. 2001. "Hardship among Children of Immigrants: Findings from the 1999 National Survey of America's Families," The Urban Institute, No B-29.

Danziger, Sheldon H. 1999. Economic Conditions and Welfare Reform, Kalamazoo, MI: Upjohn Institute.

De Jong, Gordon F and Anna B. Madamba. 2001. "A Double Disadvantage? Minority Group, Immigrants Status, and Underemployment in The United States," Social Science Quarterly, 82(1), 117-30.

Figlio, David N. and James P. Ziliak. 1999. "Welfare Reform, the Business Cycle, and the Decline in AFDC Caseloads," Pp. 17-48 in Economic Conditions and Welfare Reform, Sheldon Danziger, ed. Kalamazoo, MI: Upjohn Institute. 
Fix, Michael and Jeffrey S. Passel. 1999. "Trends in Noncitizens ' and Citizens' use of Public benefits Following Welfare Reform: 1994-97,” Urban Institute.

Greenhouse, Steven. "Hispanic Workers Die at Higher Rate," The New York Times, July 16, 2001.

Hoynes, Hilary W. 2000. "Local Labor Markets and Welfare Spells: Do Demand Conditions Matter?" Review of Economics and Statistics, 82(3), 351-368.

Hsueh, Sheri and Marta Tienda. 1995. "Earnings Consequences of Employment Instability among Minority Men, Research in Social Stratification and Mobility, 14:39-69.

Moffitt, Robert A. 1999. "The Effect of Pre-PRWORA Waivers on AFDC Caseloads and Female Earnings, Income, and Labor Force Behavior,” Pp. 91-118 in Economic Conditions and Welfare Reform, Sheldon Danziger, ed. Kalamazoo, MI: Upjohn Institute.

Passel, Jeffrey S. 1996. "Problem with March 1994 and 1995 CPS Weighting," Technical memorandum to CPS user, The Urban Institute, November.

Penner, Rudolph G, Isabel V. Sawhill and Timothy Taylor. 2000. Updating America's Social Contract, Norton, New York.

Raijman, Rebecca and Marta Tienda. 1999. "Immigrants' Socioeconomic Progress Post-1965: Forging Mobility or Survival?," Pp. 239-56 in The Handbook of International Migration: The American Experience, Charles Hirschman, Philip Kasinitz and Josh DeWind eds. Russell Sage Foundation, New York.

Schoeni, Robert and Rebecca Blank. 2000. "What Has Welfare Reform Accomplished? Impacts on Welfare Participation, Employment, Income, Poverty, and Family Structure," National Bureau of Economic Research Working Paper 7627.

Van Hook, Jennifer, Jennifer E. Glick, and Frank D. Bean. 1999. "Immigrant and Native Public Assistance Receipt: How the Unit of Analysis Affects Research Findings," Demography 36(1): 111-120.

Wallace, Geoffrey and Rebecca M. Blank. 1999. "What Goes Up Must Come Down? Explaining Recent Changes in Public Assistance Caseloads," Pp. 49-90 in Economic Conditions and Welfare Reform, Sheldon Danziger, ed. Kalamazoo, MI: Upjohn Institute.

Zimmermann, Wendy and Karen C. Tumlin. 1999. "Patchwork Policies: State Assistance for Immigrants under Welfare Reform,” The Urban Institute.

Zimmermann, Wendy and Michael Fix. 1998. "Declining Immigrant Applications for Medi-Cal and Welfare Benefits in Los Angeles County," The Urban Institute. 
Table 1. Welfare Participation Rates and Local Labor Market Conditions, Immigrant and Native Households, 1994-1999.

\begin{tabular}{|c|c|c|c|c|c|c|c|c|c|}
\hline & \multirow{2}{*}{\multicolumn{3}{|c|}{$\begin{array}{c}\text { Welfare Participation } \\
\text { Participation in Any Program }\end{array}$}} & \multicolumn{6}{|c|}{ Labor Market Conditions } \\
\hline & & & & \multicolumn{3}{|c|}{ Unemployment } & \multicolumn{3}{|c|}{ Employment-to-Population } \\
\hline & $\begin{array}{c}\text { Pre- } \\
\text { Reform }\end{array}$ & $\begin{array}{c}\text { Post- } \\
\text { Reform }\end{array}$ & $\begin{array}{c}\text { Difference } \\
\text { Post-Pre }\end{array}$ & $\begin{array}{c}\text { Pre- } \\
\text { Reform }\end{array}$ & $\begin{array}{c}\text { Post- } \\
\text { Reform }\end{array}$ & $\begin{array}{c}\text { Difference } \\
\text { Post-Pre }\end{array}$ & $\begin{array}{c}\text { Pre- } \\
\text { Reform }\end{array}$ & $\begin{array}{c}\text { Post- } \\
\text { Reform }\end{array}$ & $\begin{array}{c}\text { Difference } \\
\text { Post-Pre }\end{array}$ \\
\hline & \multicolumn{9}{|c|}{ All States } \\
\hline Natives & 15.2 & 13.6 & -1.7 & 4.7 & 3.6 & -1.1 & 79.7 & 80.2 & 0.6 \\
\hline \multirow[t]{2}{*}{ Immigrants } & 23.8 & 20.1 & -3.7 & 7.4 & 4.6 & -2.8 & 75.7 & 78.7 & 3.0 \\
\hline & \multicolumn{9}{|c|}{ California } \\
\hline Natives & 14.8 & 13.2 & -1.5 & 6.8 & 4.2 & -2.6 & 77.7 & 80.1 & 2.4 \\
\hline \multirow[t]{2}{*}{ Immigrants } & 31.3 & 23.9 & -7.4 & 9.1 & 6.0 & -3.1 & 72.7 & 77.5 & 4.8 \\
\hline & \multicolumn{9}{|c|}{ All States, Excluding California } \\
\hline Natives & 15.3 & 13.6 & -1.7 & 4.5 & 3.6 & -0.9 & 79.9 & 80.3 & 0.4 \\
\hline \multirow[t]{2}{*}{ Immigrants } & 20.4 & 18.5 & -2.0 & 6.7 & 4.0 & -2.6 & 77.2 & 79.2 & 2.0 \\
\hline & \multicolumn{9}{|c|}{ New York } \\
\hline Natives & 17.5 & 16.9 & -0.7 & 5.6 & 4.6 & -1.0 & 74.4 & 74.1 & -0.3 \\
\hline \multirow[t]{2}{*}{ Immigrants } & 23.4 & 26.8 & 3.4 & 9.2 & 5.9 & -3.3 & 69.1 & 71.6 & 2.5 \\
\hline & \multicolumn{9}{|c|}{ All States, Excluding California and New York } \\
\hline Natives & 15.1 & 13.4 & $-1 . \overline{7}$ & 4.4 & 3.5 & -0.9 & 80.3 & 80.7 & 0.4 \\
\hline Immigrants & 19.6 & 16.3 & -3.3 & 6.1 & 3.6 & -2.5 & 79.3 & 81.1 & 1.8 \\
\hline
\end{tabular}

Source: $1995-2000$ March CPS.

Note: Participation in any program refers to participation in any of the AFDC/TANF, SSI, Medicaid or Food stamp programs. Pre-reform years are 1994-95 and post-reform years are 1997-99. 
Table 2. Welfare Participation Rates and Local Labor Market Conditions by Selected Areas, Immigrants and Natives, 1994-1999.

\begin{tabular}{|c|c|c|c|c|c|c|}
\hline \multirow[b]{4}{*}{ Area } & \multicolumn{6}{|c|}{ Welfare Participation } \\
\hline & \multicolumn{3}{|c|}{ Natives } & \multicolumn{3}{|c|}{ Immigrants } \\
\hline & Pre- & Post- & Post-Pre & Pre- & Post- & Post-Pre \\
\hline & Reform & Reform & Reform & Reform & Reform & Reform \\
\hline LA/Long Beach & 14.6 & 12.9 & -1.7 & 32.4 & 25.3 & -7.2 \\
\hline Orange County & 8.9 & 7.8 & -1.1 & 33.3 & 17.7 & -15.6 \\
\hline San Jose & 9.7 & 6.1 & -3.6 & 15.4 & 15.2 & -0.2 \\
\hline San Francisco & 8.3 & 8.2 & -0.1 & 21.4 & 11.9 & -9.5 \\
\hline Miami & 15.5 & 15.3 & -0.2 & 23.1 & 20.1 & -3.0 \\
\hline Illinois & 16.2 & 12.4 & -3.9 & 15.0 & 12.0 & -3.0 \\
\hline Newark & 12.9 & 11.6 & -1.3 & 12.0 & 13.5 & 1.5 \\
\hline New York City & 24.9 & 22.1 & -2.7 & 25.5 & 27.7 & 2.2 \\
\hline Dallas & 8.9 & 9.3 & 0.4 & 14.6 & 13.3 & -1.2 \\
\hline Houston & 19.1 & 9.5 & -9.6 & 23.3 & 15.2 & -8.1 \\
\hline \multirow[t]{4}{*}{ Other U.S. } & 15.9 & 14.1 & -1.8 & 17.8 & 13.7 & -4.1 \\
\hline & \multicolumn{6}{|c|}{ Unemployment } \\
\hline & \multicolumn{3}{|c|}{ Natives } & \multicolumn{3}{|c|}{ Immigrants } \\
\hline & Pre- & Post- & Post-Pre & Pre- & Post- & Post-Pre \\
\hline Area & Reform & Reform & Reform & Reform & Reform & Reform \\
\hline LA/Long Beach & 6.9 & 4.5 & -2.4 & 9.8 & 5.6 & -4.2 \\
\hline Orange County & 6.1 & 2.8 & -3.3 & 9.5 & 3.6 & -5.9 \\
\hline San Jose & 3.7 & 1.5 & -2.2 & 1.6 & 4.0 & 2.3 \\
\hline San Francisco & 3.1 & 2.4 & -0.7 & 5.9 & 7.1 & 1.2 \\
\hline Miami & 4.9 & 6.9 & 2.0 & 6.0 & 3.8 & -2.2 \\
\hline Illinois & 4.1 & 3.5 & -0.6 & 6.0 & 4.1 & -2.0 \\
\hline Newark & 7.4 & 6.0 & -1.5 & 8.7 & 8.7 & 0.0 \\
\hline New York City & 6.3 & 7.0 & 0.7 & 10.4 & 6.9 & -3.5 \\
\hline Dallas & 2.2 & 3.4 & 1.2 & 4.3 & 1.5 & -2.8 \\
\hline Houston & 5.0 & 3.1 & -2.0 & 4.7 & 4.5 & -0.2 \\
\hline \multirow[t]{4}{*}{ Other U.S. } & 4.4 & 3.7 & -0.7 & 4.9 & 3.2 & -1.7 \\
\hline & \multicolumn{6}{|c|}{ Employment } \\
\hline & \multicolumn{3}{|c|}{ Natives } & \multicolumn{3}{|c|}{ Immigrants } \\
\hline & Pre- & Post- & Post-Pre & Pre- & Post- & Post-Pre \\
\hline Area & Reform & Reform & Reform & Reform & Reform & Reform \\
\hline LA/Long Beach & 77.1 & 79.9 & 2.8 & 70.3 & 77.1 & 6.7 \\
\hline Orange County & 82.7 & 83.9 & 1.1 & 71.4 & 85.9 & 14.6 \\
\hline San Jose & 85.7 & 84.9 & -0.8 & 87.4 & 82.0 & -5.5 \\
\hline San Francisco & 84.0 & 87.1 & 3.1 & 86.3 & 77.1 & -9.2 \\
\hline Miami & 74.3 & 80.2 & 5.9 & 78.8 & 81.8 & 3.0 \\
\hline Illinois & 80.6 & 82.7 & 2.1 & 78.0 & 81.4 & 3.4 \\
\hline Newark & 73.1 & 78.7 & 5.6 & 80.8 & 75.8 & -5.0 \\
\hline New York City & 67.6 & 68.2 & 0.6 & 67.5 & 69.8 & 2.3 \\
\hline Dallas & 87.5 & 84.4 & -3.1 & 85.8 & 89.9 & 4.1 \\
\hline Houston & 82.1 & 83.1 & 1.0 & 87.4 & 81.7 & -5.7 \\
\hline Other U.S. & 80.4 & 80.8 & 0.4 & 81.1 & 82.5 & 1.5 \\
\hline
\end{tabular}

Source: 1994-2000 March CPS.

Note: Participation in any program refers to participation in any of the AFDC/TANF, SSI, Medicaid or

Food stamp programs. Pre-reform years are 1994-95 and post-reform years are 1997-99. 
Table 3. Linear Probability Models of Welfare Participation, Any Program.

\begin{tabular}{|c|c|c|c|c|c|c|c|c|}
\hline Variable & Model 1 & Model 2 & Model 3 & Model 4 & Model 5 & Model 6 & Model 7 & Model 8 \\
\hline Intercept & $\begin{array}{c}0.158 \\
(102.97)\end{array}$ & $\begin{array}{c}0.655 \\
(49.75)\end{array}$ & $\begin{array}{c}0.659 \\
(50.06)\end{array}$ & $\begin{array}{c}0.898 \\
(28.64)\end{array}$ & $\begin{array}{c}0.884 \\
(23.47)\end{array}$ & $\begin{array}{c}0.874 \\
(23.90)\end{array}$ & $\begin{array}{c}0.876 \\
(20.16)\end{array}$ & $\begin{array}{c}0.915 \\
(28.31)\end{array}$ \\
\hline Post-Reform & $\begin{array}{l}-0.020 \\
(10.04)\end{array}$ & $\begin{array}{l}-0.015 \\
(8.76)\end{array}$ & $\begin{array}{l}-0.015 \\
(8.61)\end{array}$ & $\begin{array}{l}-0.011 \\
(5.75)\end{array}$ & $\begin{array}{l}-0.011 \\
(6.07)\end{array}$ & $\begin{array}{l}-0.010 \\
(5.13)\end{array}$ & $\begin{array}{l}-0.011 \\
(5.55)\end{array}$ & $\begin{array}{l}-0.005 \\
(1.46)\end{array}$ \\
\hline Immigrants & $\begin{array}{c}0.077 \\
(15.61)\end{array}$ & $\begin{array}{l}0.041 \\
(4.26)\end{array}$ & $\begin{array}{l}0.039 \\
(4.07)\end{array}$ & $\begin{array}{l}0.024 \\
(2.53)\end{array}$ & $\begin{array}{l}0.028 \\
(2.86)\end{array}$ & $\begin{array}{l}0.093 \\
(1.47)\end{array}$ & $\begin{array}{l}0.050 \\
(0.78)\end{array}$ & $\begin{array}{l}-0.023 \\
(1.31)\end{array}$ \\
\hline Immigrant ${ }^{\star}$ Post-Reform & $\begin{array}{l}-0.022 \\
(3.62)\end{array}$ & $\begin{array}{r}-0.018 \\
(3.21)\end{array}$ & $\begin{array}{r}-0.018 \\
(3.20)\end{array}$ & $\begin{array}{r}-0.006 \\
(0.96)\end{array}$ & $\begin{array}{r}-0.007 \\
(1.24)\end{array}$ & $\begin{array}{l}-0.009 \\
(1.38)\end{array}$ & $\begin{array}{l}-0.009 \\
(1.47)\end{array}$ & $\begin{array}{l}0.003 \\
(0.37)\end{array}$ \\
\hline Unemployment Rate & & & & $\begin{array}{l}0.315 \\
(3.97)\end{array}$ & $\begin{array}{l}0.247 \\
(2.86)\end{array}$ & $\begin{array}{l}0.415 \\
(4.02)\end{array}$ & $\begin{array}{l}0.310 \\
(2.79)\end{array}$ & $\begin{array}{l}0.315 \\
(3.94)\end{array}$ \\
\hline Employment Rate & & & & $\begin{array}{l}-0.321 \\
(9.78)\end{array}$ & $\begin{array}{l}-0.298 \\
(7.24)\end{array}$ & $\begin{array}{l}-0.297 \\
(7.60)\end{array}$ & $\begin{array}{l}-0.292 \\
(6.07)\end{array}$ & $\begin{array}{l}-0.336 \\
(10.00)\end{array}$ \\
\hline Immigrant* Unemployment & & & & & & $\begin{array}{c}-0.237 \\
(1.46)\end{array}$ & $\begin{array}{c}-0.134 \\
(0.81)\end{array}$ & \\
\hline Immigrant`Employment & & & & & & $\begin{array}{l}-0.070 \\
(0.98)\end{array}$ & $\begin{array}{l}-0.019 \\
(0.26)\end{array}$ & \\
\hline $\begin{array}{l}\text { Model Controls for Individual } \\
\text { Characteristics }\end{array}$ & No & Yes & Yes & Yes & Yes & Yes & Yes & Yes \\
\hline $\begin{array}{l}\text { Model Includes Immigrant State } \\
\text { Fixed Effects }\end{array}$ & No & No & Yes & No & Yes & No & Yes & No \\
\hline $\begin{array}{l}\text { Model Includes Controls for } \\
\text { Benefit Levels and Availability }\end{array}$ & No & No & No & No & No & No & No & Yes \\
\hline Number of Observ & \multicolumn{8}{|c|}{203,296} \\
\hline R-squared & 0.004 & 0.183 & 0.184 & 0.184 & 0.185 & 0.184 & 0.185 & 0.184 \\
\hline
\end{tabular}

Source: $1995-2000$ March CPS.

Note: The individual and household characteristics included in Models 2-8 are controls for age, education, urban resident, gender, marital status, number of individuals in the household, number of children under the age of 18 and for immigrants, arrival cohort (the reference cohort is the post-1992 arrival cohort). The immigrant states in the table refer to Arizona, California, Florida, Illinois, Massachusetts, Michigan, Nevada, New Jersey, New York and Texas. Model 8 includes controls for 1997 TANF benefit levels for a family of three and the Urban Institute's index for state specific availability of welfare to non-citizen immigrants. The model also includes these variables interacted with the post reform indicator variable and the immigrant indicator variable. Furthermore, t-values, based on robust standard errors, appear in parentheses. 
Table 4. Linear Probability Models of Welfare Participation, Specific Programs.

\begin{tabular}{|c|c|c|c|c|c|c|c|c|}
\hline \multirow{2}{*}{$\begin{array}{l}\text { Public Assistance Program: } \\
\text { Variable }\end{array}$} & \multicolumn{2}{|c|}{ AFDC/TANF } & \multicolumn{2}{|c|}{$\overline{\text { SSI }}$} & \multicolumn{2}{|c|}{ Food Stamps } & \multicolumn{2}{|c|}{ Medicaid } \\
\hline & Model 2 & Model 4 & Model 2 & Model 4 & Model 2 & Model 4 & Model 2 & Model 4 \\
\hline Intercept & $\begin{array}{l}0.2618 \\
(31.69)\end{array}$ & $\begin{array}{l}0.4301 \\
(22.24)\end{array}$ & $\begin{array}{c}0.0420 \\
(6.20)\end{array}$ & $\begin{array}{c}0.1620 \\
(9.09)\end{array}$ & $\begin{array}{l}0.4550 \\
(44.37)\end{array}$ & $\begin{array}{l}0.5734 \\
(24.49)\end{array}$ & $\begin{array}{l}0.5930 \\
(46.23)\end{array}$ & $\begin{array}{l}0.9066 \\
(29.64)\end{array}$ \\
\hline Post-Reform & $\begin{array}{l}-0.0203 \\
(19.86)\end{array}$ & $\begin{array}{l}-0.0161 \\
(14.74)\end{array}$ & $\begin{array}{l}0.0010 \\
(0.95)\end{array}$ & $\begin{array}{l}0.0013 \\
(1.20)\end{array}$ & $\begin{array}{l}-0.0228 \\
(17.04)\end{array}$ & $\begin{array}{r}-0.0197 \\
(13.91)\end{array}$ & $\begin{array}{c}-0.0095 \\
(5.63)\end{array}$ & $\begin{array}{c}-0.0047 \\
(2.66)\end{array}$ \\
\hline Immigrants & $\begin{array}{l}0.0177 \\
(3.12)\end{array}$ & $\begin{array}{l}0.0043 \\
(0.76)\end{array}$ & $\begin{array}{c}-0.0072 \\
(1.59)\end{array}$ & $\begin{array}{c}-0.0105 \\
(2.27)\end{array}$ & $\begin{array}{l}0.0206 \\
(3.02)\end{array}$ & $\begin{array}{l}0.0109 \\
(1.59)\end{array}$ & $\begin{array}{r}0.0381 \\
(4.11)\end{array}$ & $\begin{array}{c}0.0204 \\
(2.18)\end{array}$ \\
\hline Immigrant ${ }^{\star}$ Post-Reform & $\begin{array}{c}-0.0115 \\
(3.37)\end{array}$ & $\begin{array}{c}-0.0008 \\
(0.24)\end{array}$ & $\begin{array}{c}-0.0037 \\
(1.20)\end{array}$ & $\begin{array}{c}-0.0013 \\
(0.42)\end{array}$ & $\begin{array}{c}-0.0217 \\
(5.17)\end{array}$ & $\begin{array}{c}-0.0139 \\
(3.28)\end{array}$ & $\begin{array}{c}-0.0161 \\
(2.89)\end{array}$ & $\begin{array}{c}-0.0022 \\
(0.39)\end{array}$ \\
\hline Unemployment Rate & & $\begin{array}{c}0.3144 \\
(6.38)\end{array}$ & & $\begin{array}{c}-0.0581 \\
(1.29)\end{array}$ & & $\begin{array}{l}0.2362 \\
(4.14)\end{array}$ & & $\begin{array}{l}0.2630 \\
(3.39)\end{array}$ \\
\hline Employment Rate & & $\begin{array}{l}-0.2280 \\
(11.27)\end{array}$ & & $\begin{array}{l}-0.1466 \\
(7.78)\end{array}$ & & $\begin{array}{c}-0.1612 \\
(6.61)\end{array}$ & & $\begin{array}{l}-0.4066 \\
(12.68)\end{array}$ \\
\hline Number of & & 96 & & & & 96 & & \\
\hline R-squared & 0.1656 & 0.1685 & 0.0421 & 0.0426 & 0.1850 & 0.1859 & 0.1699 & 0.1720 \\
\hline
\end{tabular}

Source: 1995-2000 March CPS.

Note: Model number refers to Models in Table 3. The individual and household characteristics included in all Models are controls for age, education, urban resident, gender, marital status, number of individuals in the household, number of children under the age of 18 and for immigrants, arrival cohort (the reference cohort is the post-1992 arrival cohort). Furthermore, t-values, based on robust standard errors, appear in parentheses. 


$$
1 / 21
$$




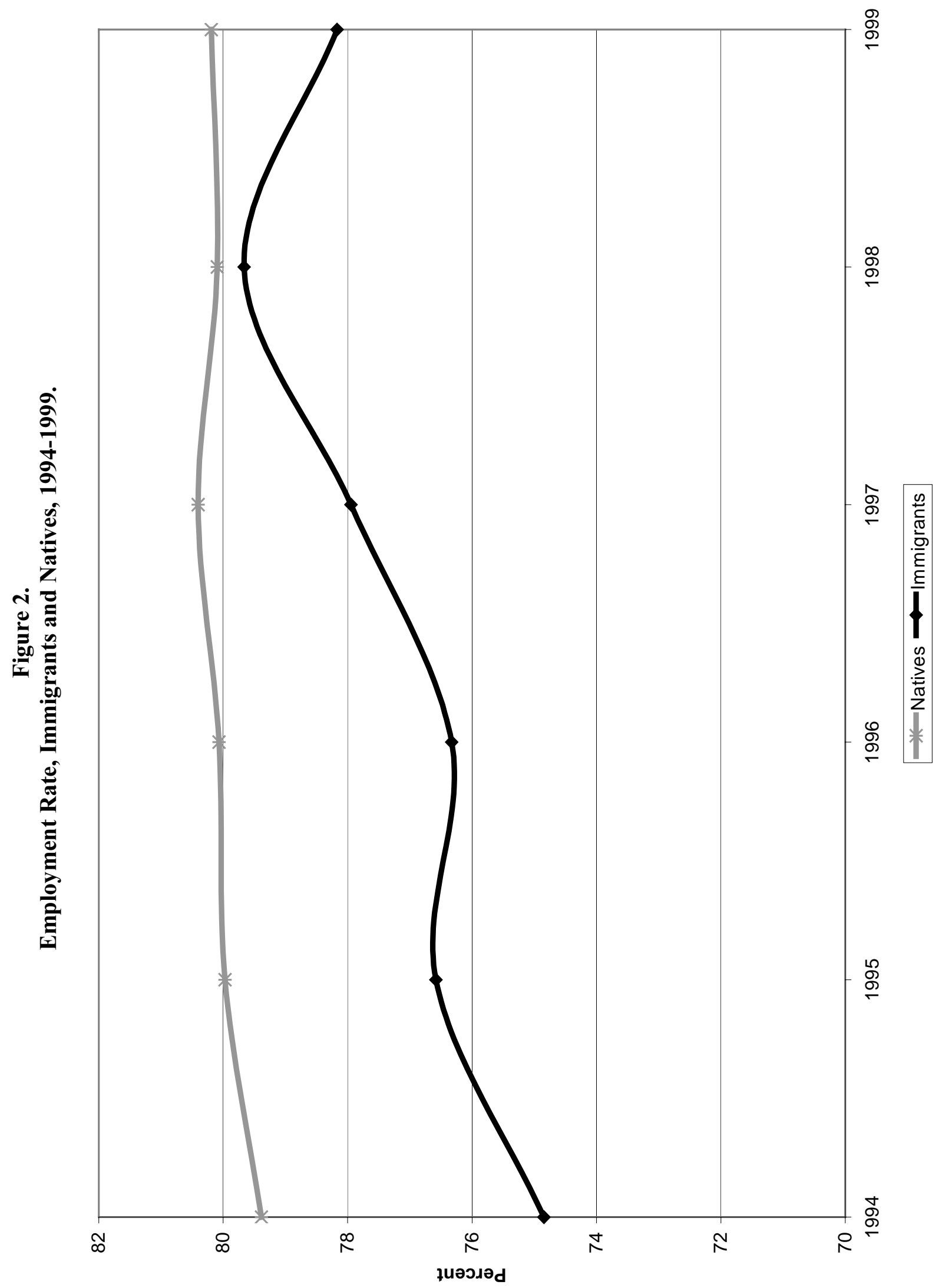




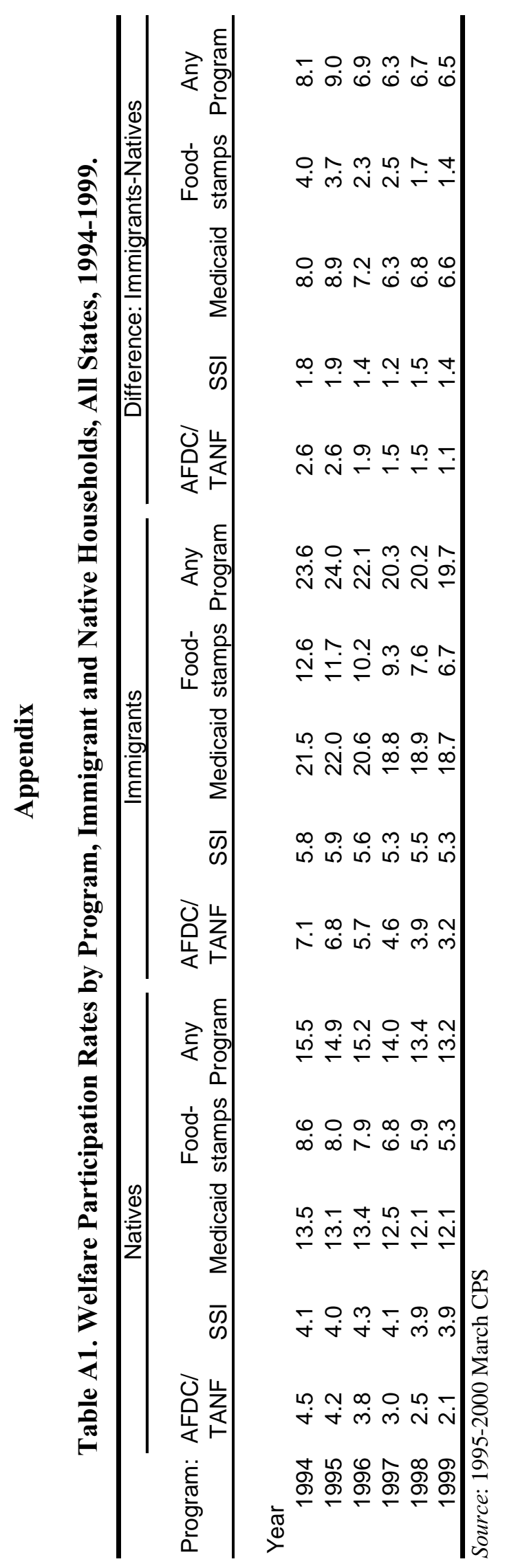



Table A2. Mean Period Unemployment and Employment by Geographic Areas, Immigrants and Natives, 1994-1999.

\begin{tabular}{|c|c|c|c|c|c|c|c|c|c|c|}
\hline \multirow[b]{3}{*}{ Area } & \multicolumn{5}{|c|}{ Natives } & \multicolumn{5}{|c|}{ Immigrants } \\
\hline & \multicolumn{3}{|c|}{ Unemployment } & \multicolumn{2}{|c|}{ Employment } & \multicolumn{3}{|c|}{ Unemployment } & \multicolumn{2}{|c|}{ Employment } \\
\hline & Obs & Mean & St. Dev. & Mean & St. Dev. & Obs & Mean & St. Dev. & Mean & St. Dev. \\
\hline Arizona & 3,016 & 3.77 & 0.96 & 79.65 & 2.00 & 687 & 4.11 & 3.31 & 71.80 & 5.63 \\
\hline LA/Long Beach & 4,900 & 5.14 & 1.48 & 78.63 & 2.10 & 4,727 & 6.83 & 2.72 & 74.51 & 3.14 \\
\hline Orange County & 943 & 3.96 & 2.31 & 84.29 & 2.26 & 531 & 4.75 & 3.54 & 80.20 & 7.01 \\
\hline San Diego & 1,056 & 5.28 & 1.47 & 80.72 & 2.65 & 448 & 6.20 & 4.14 & 76.09 & 6.07 \\
\hline San Jose & 618 & 2.51 & 1.67 & 84.08 & 2.51 & 354 & 2.72 & 1.39 & 83.95 & 2.88 \\
\hline Riverside/San Bernardino & 1,139 & 5.15 & 2.46 & 75.78 & 3.01 & 356 & 3.76 & 0.84 & 79.66 & 6.08 \\
\hline San Francisco & 755 & 2.65 & 1.13 & 86.17 & 2.25 & 309 & 5.93 & 2.03 & 81.77 & 5.74 \\
\hline Other California & 4,641 & 5.84 & 2.17 & 77.27 & 2.11 & 1,388 & 11.50 & 2.03 & 71.49 & 1.92 \\
\hline Fort Lauderdale & 896 & 2.40 & 2.07 & 86.72 & 3.81 & 366 & 3.57 & 2.23 & 80.07 & 5.66 \\
\hline Miami & 722 & 5.47 & 2.38 & 79.81 & 4.93 & 1,422 & 4.58 & 1.28 & 80.25 & 3.40 \\
\hline Other Florida & 7,502 & 3.25 & 1.11 & 76.91 & 1.49 & 841 & 5.32 & 2.91 & 76.05 & 3.09 \\
\hline Illinois & 8,711 & 3.81 & 0.75 & 81.98 & 1.34 & 1,470 & 4.69 & 1.89 & 80.73 & 3.24 \\
\hline Massachusetts & 6,226 & 4.07 & 0.86 & 79.20 & 1.46 & 899 & 5.91 & 3.92 & 78.16 & 6.40 \\
\hline Michigan & 8,431 & 4.13 & 1.53 & 79.10 & 1.59 & 480 & 3.02 & 2.52 & 78.57 & 5.70 \\
\hline Nevada & 2,599 & 3.50 & 1.18 & 81.44 & 3.00 & 499 & 3.10 & 1.51 & 87.23 & 3.78 \\
\hline Bergen-Passaic & 1,004 & 3.27 & 1.65 & 82.40 & 3.08 & 441 & 6.28 & 4.79 & 81.92 & 5.00 \\
\hline Jersey City & 378 & 6.71 & 3.95 & 71.46 & 5.86 & 350 & 8.52 & 6.17 & 74.99 & 8.49 \\
\hline Newark & 1,552 & 5.83 & 2.32 & 76.79 & 3.27 & 480 & 7.98 & 3.53 & 78.04 & 4.40 \\
\hline Other New Jersey & 3,760 & 4.03 & 0.64 & 80.58 & 1.08 & 442 & 3.87 & 1.38 & 83.95 & 3.34 \\
\hline New York City & 5,468 & 6.55 & 1.93 & 68.15 & 2.67 & 3,651 & 7.87 & 2.46 & 69.61 & 2.40 \\
\hline Other New York state & 7,096 & 4.50 & 1.24 & 77.60 & 1.13 & 585 & 2.87 & 0.84 & 77.44 & 2.85 \\
\hline Dallas & 1,754 & 2.73 & 0.99 & 84.93 & 2.13 & 377 & 2.82 & 2.46 & 87.56 & 4.02 \\
\hline Houston & 2,086 & 3.42 & 1.24 & 82.72 & 1.34 & 632 & 4.56 & 1.18 & 83.58 & 2.80 \\
\hline Other Texas & 7,540 & 3.59 & 0.79 & 81.73 & 1.03 & 1,233 & 6.84 & 2.77 & 77.09 & 2.25 \\
\hline Other U.S. & 134,380 & 3.97 & 0.50 & 80.68 & 0.36 & 6,750 & 4.20 & 1.27 & 81.25 & 2.08 \\
\hline
\end{tabular}

Source: 1994-1999 March CPS. 


\section{IZA Discussion Papers}

\begin{tabular}{|c|c|c|c|c|}
\hline No. & Author(s) & Title & Area & Date \\
\hline 270 & $\begin{array}{l}\text { B. Augurzky } \\
\text { C. M. Schmidt }\end{array}$ & $\begin{array}{l}\text { The Evaluation of Community-Based } \\
\text { Interventions: A Monte Carlo Study }\end{array}$ & 6 & $03 / 01$ \\
\hline 271 & $\begin{array}{l}\text { B. Augurzky } \\
\text { C. M. Schmidt }\end{array}$ & The Propensity Score: A Means to An End & 6 & $03 / 01$ \\
\hline 272 & $\begin{array}{l}\text { C. Belzil } \\
\text { J. Hansen }\end{array}$ & $\begin{array}{l}\text { Heterogeneous Returns to Human Capital and } \\
\text { Dynamic Self-Selection }\end{array}$ & 5 & $03 / 01$ \\
\hline 273 & G. Saint-Paul & $\begin{array}{l}\text { Distribution and Growth in an Economy with } \\
\text { Limited Needs }\end{array}$ & 5 & $03 / 01$ \\
\hline 274 & $\begin{array}{l}\text { P.J. Pedersen } \\
\text { N. Smith }\end{array}$ & $\begin{array}{l}\text { Unemployment Traps: Do Financial Dis- } \\
\text { incentives Matter? }\end{array}$ & 3 & $03 / 01$ \\
\hline 275 & $\begin{array}{l}\text { G. S. Epstein } \\
\text { T. Lecker }\end{array}$ & $\begin{array}{l}\text { Multi-Generation Model of Immigrant Earnings: } \\
\text { Theory and Application }\end{array}$ & 1 & $03 / 01$ \\
\hline 276 & $\begin{array}{l}\text { B. Amable } \\
\text { D. Gatti }\end{array}$ & $\begin{array}{l}\text { The Impact of Product Market Competition on } \\
\text { Employment and Wages }\end{array}$ & 5 & $03 / 01$ \\
\hline 277 & R. Winter-Ebmer & $\begin{array}{l}\text { Evaluating an Innovative Redundancy-Retraining } \\
\text { Project: The Austrian Steel Foundation }\end{array}$ & 6 & $03 / 01$ \\
\hline 278 & T. M. Andersen & $\begin{array}{l}\text { Welfare Policies, Labour Taxation and Inter- } \\
\text { national Integration }\end{array}$ & 2 & $04 / 01$ \\
\hline 279 & T. M. Andersen & $\begin{array}{l}\text { Product Market Integration, Wage Dispersion } \\
\text { and Unemployment }\end{array}$ & 2 & $04 / 01$ \\
\hline 280 & $\begin{array}{l}\text { P. Apps } \\
\text { R. Rees }\end{array}$ & $\begin{array}{l}\text { Household Saving and Full Consumption over } \\
\text { the Life Cycle }\end{array}$ & 7 & $04 / 01$ \\
\hline 281 & G. Saint-Paul & $\begin{array}{l}\text { Information Technology and the Knowledge } \\
\text { Elites }\end{array}$ & 5 & $04 / 01$ \\
\hline 282 & $\begin{array}{l}\text { J. Albrecht } \\
\text { A. Björklund } \\
\text { S. Vroman }\end{array}$ & Is There a Glass Ceiling in Sweden? & 5 & $04 / 01$ \\
\hline
\end{tabular}



to Internal Promotion for Young U.S. Men and Women and the Rising Returns to Skill: US and France 1964-2000 Insurance Compensation on the Labor Market Histories of Displaced Workers 

H. Bonin
G. Abío
E. Berenguer
J. Gil
C. Patxot

Is the Deficit under Control? A Generational 

A. Frederiksen
Overtime Work, Dual Job Holding and Taxation 

A. lbourk
B. Maillard
S. Perelman
H. R. Sneessens

The Matching Efficiency of Regional Labour

Markets: A Stochastic Production Frontier 